\title{
CONTINUITY AND CHANGE IN EIGHTEENTH-CENTURY MEDICAL WRITING IN ENGLISH
}

\author{
IRMA TAAVITSAINEN (*)
}

\begin{abstract}
We need to ask how language conditioned scientific thinking and was in turn altered by it ${ }^{1}$.
\end{abstract}

SunTO. - Gli sviluppi scientifici e medici del secolo XVIII hanno una rilevanza diretta per il nostro mondo moderno in quanto spianarono la strada a pratiche più moderne. Questo saggio offre una panoramica degli scritti medici inglesi del Settecento quando, ad esempio, nuovi strumenti tecnici come il microscopio aprirono nuovi orizzonti, fece i primi passi la medicina di laboratorio, e si sviluppò e si diversificò la divulgazione delle conoscenze mediche. La mia valutazione è qualitativa ma si basa sulla chiara evidenza quantitativa di dati linguistici mediante l'innovativa metodologia dell'informatica umanistica che ha rivelato le tendenze al mutamento e le ha messe in un ordine gerarchico. Elemento ancora più importante, la medicina raggiunse nel Settecento un nuovo livello di professionalità. Si iniziò a dare più attenzione alla salute pubblica, vennero fondate nuove istituzioni, e nuovi argomenti emersero con l'espansione dell'impero britannico.

$* * *$

ABSTRACT. - Eighteenth-century scientific and medical developments have direct relevance to our modern world as they paved the way towards more modern practices. This article presents an overview of English medical writing during the century when, for example, new technical equipment like the microscope opened up new horizons, laboratory medicine took its first steps, and dissemination of medical knowledge developed and diversified. My assessment is qualitative but based on firm quantitative evidence of linguistic data by an innovative Digital Humanities method that revealed the changing trends and put them in ranking order. Most importantly, medicine achieved a new level of professionalization in the eighteenth century. More attention started to be paid to public health, new institutions were founded, and new topics emerged with the expansion of the British Empire.

(*) University of Helsinki, Finland. E-mail: irma.taavitsainen@helsinki.fi

1 A. C. Crombie, Styles of scientific thinking in the European tradition, 3 vols, London, Duckworth, 1994, 1, 11. 


\section{THE AIM AND THE PLAN OF THIS ARTICLE}

Tracing developments in eighteenth-century scientific and medical writing poses several challenges and calls for a bird's-eye view of what took place within the period. The aim of this article is to present an overview of English medical writing in the eighteenth century with focus on professional texts, but texts intended for a lay audience are also included. I shall start my chapter by summarizing what the earlier literature tells us about the period. A more precise timeline of continuities and changes emerges with an application of a new Digital Humanities method to carefully compiled linguistic corpus data of medical texts (see below). In general, the late modern period has received less attention in the previous literature than the early modern ${ }^{2}$, but their developments are closely connected as the survey will show.

\section{GENERAL CHARACTERIZATIONS OF THE PERIOD}

Various labels have been used to characterize the profound transformations that Britain experienced during the eighteenth century. It has been pointed out that a commonly used term 'Medical Enlightenment' is anachronistic but covers both professional and lay sides: it catches the appearance of new views on human nature and changing moral values, canons of taste and styles of sociability, in addition to «transformations in casts of mind, habits of thinking and shades of sensibility, and their diffusion among the reading public» ${ }^{3}$. Other terms used of eighteenth-century medical developments have different shades of meaning. 'Proliferation of systems' remains vague in the literature ${ }^{4}$, but seems to refer to the prevailing and competing traits of the

2 There are several collected volumes with historians' summaries of the eighteenth century, but what is still lacking is a seminal presentation like A. Wear, Knowledge and practice in English medicine, 1550-1680, Cambridge, Cambridge University Press, 2000.

3 R. Porter, Enlightenment: Britain and the creation of the modern world, London, Penguin Books, 2000, 13-14. The term is also used as a book title in A. Cunningham and R. French (eds), The medical Enlightenment of the eighteenth century, Cambridge, Cambridge University Press, 1990.

4 A. Cunningham and R. French (eds), The medical Enlightenment of the 
century in a competition between explanatory medical systems. Another side of the coin, with competing systems as well, can be found in the multi-layered medical market and the unstructured nature of medical care available to the population at large. A third label attached to the eighteenth century is «[t] he golden age of quackery» ${ }^{5}$. It casts light on the practices in the medical market and echoes the dismissive language that professional doctors used of services in the field to the lower end of society and practices of lay people seeking advice in health care. It also refers to the sale of medical commodities by which quacks made their profits, as expressed, e.g. in the following extract written by an educated medical practitioner, Andrew Hooke with the letters M.D. after his name:

(1) ... an infinite jumble of Medicines under the notion of Specifick Alteratives; as if, by a most unaccountable and unintelligible Transmutation, the morbid Matter could be converted into good Blood and Humours, ... which idle Conceit is without doubt the Bane of all rational Practice, and the common Cheat by which Quacks, Empyricks and Ignorant Pretenders, chowse and dupe People out of their Money and Lives. (LMEMT, Hooke, Essay on physick, 1734, 9-10)

This sharp criticism is targeted rather at the lower end of the medical practice. People sought help where they could afford it and increasingly benevolent attitudes to the poor and those in need of care can be found in the literature.

\section{DATA FOR THE STUDY}

The present assessment is largely based on the two electronic corpora compiled by the Scientific thought-styles research team at the

\footnotetext{
eighteenth century, cit., 1-3, and H. Ishizuka, 'Fibre Body': the concept of fibre in eighteenth-century medicine, c. 1700-40, Medical history 56, 4 (2012), 562-584.

5 It is discussed in the following books by Roy Porter: Quacks: fakers and charlatans in medicine, Stroud, Tempus, 2003; Disease, medicine and society in England, 1550-1860, Cambridge, Cambridge University Press, 1995 (1 ${ }^{\text {st }}$ edn 1987); Health for sale, Manchester, Manchester University Press, 1989. Also in M. S. R. Jenner and P Wallis, Medicine and the market in England and its colonies c. 1450-c. 1850, Basingstoke, Palgrave Macmillan, 2007.
} 
University of Helsinki ${ }^{6}$. The perspective of learned medical writing in the vernacular covers over four hundred years from 1375 to 1800 , but there are still uncharted areas as much of the early period remains beyond reach in their repositories or has been lost. The corpus of Late Modern English Medical Texts (LMEMT 1700-1800) ${ }^{7}$ provides the primary material for this study. The previous period is presented by the corpus of Early Modern English Medical Texts (EMEMT 1500-1700) ${ }^{8}$ that served as the point of comparison in the empirical study reported on here. The first part of the series, Middle English Medical Texts (MEMT 1375-1500) ${ }^{9}$ is referred to when discussing continuities of the more popular layers and afterlives of scholasticism. When compiling the later corpora, there were no problems in finding texts of the learned and professional type, but we faced difficulties in locating data of the more ephemeral kind as writings intended for the illiterate or the semiliterate audiences were rare or not available.

6 As A. C. Crombie makes clear, «Every society has its own cultural ecology with views of nature conditioned by its mental vision. Scientific thought-styles are defined as the underlying intellectual and moral commitments of society and culture; one of the central questions is what continued and what changed» (Styles of scientific thinking in the European tradition, cit., vol. 1, 56). Information about the research team can be found online in Corpus Resources Database (CoRD) at http://www.helsinki.fi/ varieng/CoRD/.

7 LMEMT = Late Modern English medical texts 1700-1800, compiled by I. Taavitsainen, T. Hiltunen, V. Marttila, P. Pahta, M. Ratia, C. Suhr and J. Tyrkkö, Amsterdam, John Benjamins, 2019. See I. Taavitsainen and T. Hiltunen (eds), Late Modern English medical texts: writing medicine in the eighteenth century, Amsterdam/Philadelphia, John Benjamins, 2019, and I. Taavitsainen et al., Late Modern English medical texts 1700-1800: a corpus for analysing eighteenth-century medical English, ICAME journal 38, 1 (2014), 137-153.

8 EMEMT = Early Modern English medical texts. Compiled by I. Taavitsainen, P. Pahta, T. Hiltunen, M. Mäkinen, V. Marttila, M. Ratia, C. Suhr and J. Tyrkkö, DVD with EMEMT Presenter software by R. Hickey, Amsterdam/Philadelphia, John Benjamins, 2010. See I. Taavitsainen and P. Pahta (eds), Early Modern English medical writing: corpus description and studies, Amsterdam/ Philadelphia, John Benjamins, 2010, and I. Taavitsainen and P. Pahta (eds), Medical writing in Early Modern English, Cambridge, Cambridge University Press, 2011.

9 I. Taavitsainen, P. Pahta and M. Mäkinen (compilers), Middle English Medical Texts, CD_ROM, Amsterdam/Philadelphia, John Benjamins, 2005. 


\section{ApPROACH: HistoricAl PRAGMATICS COMBINED WITH DIGITAL HUMANITIES}

The concept of scientific thought styles implies taking the societal and cultural developments into account and is very much in accordance with the approach of historical pragmatics that investigates authentic language use in its multilayered context, with cultural, sociohistorical, textual, and linguistic aspects. It aims at discovering meaning-making practices in past communication between various text participants, with their sociolinguistic parameters and situational constraints ${ }^{10}$. Texts are regarded in their larger cultural frame of the period. Pragmatics takes people into account and in historical pragmatics it is pertinent to begin with considerations of authors and audiences, as the task of providing an overview of medical writing implies a wide scope from the top to the bottom on the basis of the surviving evidence. The top level is well documented as writings by highly educated doctors are available, but other groups of people contributed to medical literature as well, including less educated men of laity and women. The target audiences vary to an even greater degree and the scope stretches from professional doctors writing to their peers and other medical practitioners to texts intended for the general public and households with women. A more comprehensive picture of the period arises by combining historical pragmatics with qualitative discourse analysis with a new digital method. A diachronic line emerges and it is possible to follow how changes progress in time and locate texts where the old ways of thinking linger on. Thus we can achieve a more detailed and accurate picture and pinpoint concrete textual evidence of what changed and what remained constant.

\section{AUTHORS AND AUDIENCES}

The highest group of professional medical practitioners was university-educated doctors. Then came trained professionals like sur-

10 See I. Taavitsainen and A. H. Jucker, Twenty years of historical pragmatics, Journal of historical pragmatics 16, 1 (2015), 1-24, and I. Taavitsainen, Meaning-making practices in the history of medical English: a sociopragmatic approach, Journal of historical pragmatics 18, 2 (2017), 252-270. 
geons who learned the trade by apprenticeship. Apothecaries were about the same level and their task was to prepare the drugs prescribed by physicians. These professional groups stood in contrast to quacks. Yet it has been noted that control was lacking in general, and «just about anyone» could perform medical tasks such as preparing medicines, performing surgical operations, or assisting at childbirth ${ }^{11}$. Progress in the eighteenth century meant developments towards more organized medical practice with changes in medical institutes, practitioners' training and social contacts ${ }^{12}$. A cultural shift in the eighteenth century demanded for more middling rank practitioners and, as a consequence, increasing opportunities were offered for education, e.g. in the post-apprenticeship phase lectures and hospital tuition became available, even to the extent that the new system rivalled university programmes ${ }^{13}$.

The earlier commonplace of writing for the poor is often present in eighteenth-century writings, too, but it has more truth in it than in the earlier periods, as public good was the leading force behind the initiatives to establish charitable institutions and provide medical care for the poor. Philanthropy was one of the rising trends especially in the latter half of the century, but it was present even earlier: in 1714, the Royal College of Physicians of London published a book called Dispensary and dedicated it «for the relief of the Sick Poor in and about London (many hundreds of whom perish yearly for want of due Care and Assistance in their Sickness)» (1714, 23, emphasis original). An anonymous text, written for oral delivery called 'address' from the year 1790, expresses the new attitudes with eloquence:

(2) THE Philanthropist and the Citizen of the World, whose benevolent feelings are interested in the welfare and preservation of mankind, and whose liberality is extended to the Support of this Institution, have, ever since its first foundation, been annually presented with one of the Sublimest Spectacles, to the enjoyment of which the human heart can

11 S. C. Lawrence, Private enterprise and public interests: medical education and the Apothecaries' Act, 1780-1825, in R. French and A. Wear (eds.), British medicine in an age of reform, London, Routledge, 2005 [1991], 45-73, 47.

12 E. Lonati, Communicating medicine: British medical discourse in eighteenthcentury Reference Works, Milano, Ledizioni, 2017, 12-13.

13 S. C. Lawrence, Private enterprise and public interests: medical education and the Apothecaries' Act, 1780-1825, cit., 48. 
possibly expand. This awful Solemnity of humanity-this noble representation of charity triumphing over death and the grave, over misfortune and despair, has at each succeeding meeting been attended with additional circumstances of exultation and gratitude, in proportion as the influence of the Society has extended, and its success increased. (LMEMT, Anon., Anniversary Address of the Royal Humane Society, 1790, preface)

Health issues were of concern to all people, and there was a growing interest in general welfare. Besides newly founded institutions, rich households and gentlewomen acted as benefactors in the care of the less privileged and a similar motivation is explained in several other writings ${ }^{14}$. In the following, a woman author, Eliza Smith, is addressing a female audience:

(3) ... for those Generous, Charitable, and Christian Gentlewomen that have a Disposition to be serviceable to their poor Country Neighbours, laboring under any of the Afflicted Circumstances mentioned; who by making Medicines, and generously contributing as occasions offer, may help the poor in their Afflictions, gain their Good-Will and Wishes, entitle themselves to their Blessings and Prayers ... (LMEMT, Smith, The compleat bousewife, 1728, A5)

\section{METHOD}

The main method of this article is qualitative analysis, but the arguments are largely based on an earlier study that was conducted at the interface between computer science, medical history and discourse analysis by a topic modeling program called MALLET ${ }^{15}$. The method employs a distributional probabilistic model: the documents are given,

14 A. Withey, Household medicine and recipe culture in eighteenth-century Britain, in I. Taavitsainen and T. Hiltunen (eds.), Late Modern English medical texts: writing medicine in the eighteenth century, Amsterdam/Philadelphia, John Benjamins, 2019, 113-128.

$15 \mathrm{http}: / /$ mallet.cs.umass.edu/topics.php. The original study is a joint effort by a historical linguist (Irma Taavitsainen), a computer scientist (Gerold Schneider) and a medical historian (Peter Murray Jones): I. Taavitsainen, G. Schneider and P. M. Jones, Topics of eighteenth-century medical writing, in I. Taavitsainen and T. Hiltunen (eds.), Late Modern English medical texts: writing medicine in the eighteenth century, cit., 31-74. 
but the topics emerge; a topic is a cluster of frequently co-occurring words. This totally data-driven approach reveals semantically related subject areas and ranks them in the order of importance. The program gives a list of topics with keywords, and it also shows the contributions of each document to the topics, which is of great use when searching for qualitative examples. It is, however, the researchers' task to interpret the word strings. A diachronic view is then achieved by comparing the topics arising in different periods.

The results of our empirical method of topic modeling partly confirmed and partly renewed the lines established in the earlier literature and, most importantly, it showed what developments have been underrated in the earlier scholarship. The results also show what remained constant, and thus a more diversified picture emerges of changing thought-styles with different developments in various traditions and genres of writing. In the following, I shall discuss the results according to their importance for the present research questions.

\section{THE ROOTS AND MEDIA OF MEDICAL WRITING IN THE EIGHTEENTH CENTURY}

(4) The diffusion of a general knowledge and of a taste for science, over all classes of men, in every nation of Europe, or of European origin, seems to be the characteristic feature of the present age. The study of sciences principally has expanded the mind, and laid it open for reception of every kind of truth. (Ker, The first part of a dictionary of chemistry $\&$ c, 1789, iii)

An appropriate point of departure for assessing eighteenth-century science is the establishment of the Royal Society in $1662^{16}$, as that year marks a major step in the development of cutting-edge science into the modern direction; this year is so important that some scholars

16 Three years earlier, the Medici court at Florence had formed the Accademia del Cimento that organized empirical experiments and published reports on them in Saggi di naturali experienze fatte nell'Accademia del Cimento. In France, the Académie royale des sciences was granted an official status by King Louis XIV in 1666 with a similar programme: see G. L'E. Turner, Eighteenth-century scientific instruments and their makers, in R. Porter (ed.), The Cambridge history of science, vol. 4, Eighteenth-century science, Cambridge, Cambridge University Press, 2003, 512. 
regard it as the starting point of the history of scientific writing in English. The Philosopbical Transactions (PT) was launched in 1665 (and continues until the present) as a general scientific periodical with medical topics among others. Specialized scientific journals were initiated in the eighteenth century with some short-lived pioneering medical journals that started to appear in Edinburgh in the 1730s and are conventionally grouped together under the title Edinburgh Medical Journal (EMJ) ${ }^{17}$. Others followed, but the most prestigious present-day medical publications, The Lancet and The British Medical Journal, were founded in the nineteenth century (1823 and 1840, respective$1 y)^{18}$. The medium has developed and branched into highly specialized periodical publications where the cutting-edge articles of medicine are nowadays published according to their disciplines or subdisciplines, and the pace is extremely rapid with real-time online distribution worldwide.

Monographs provided the main means of publication in the eighteenth century. In contrast to periodicals, they had centuries long roots in English as several learned treatises classified as monographs can be traced to the pan-European boom of translating and adapting learned Latin medical and scientific texts into late Middle English ${ }^{19}$. These early vernacular texts follow Latin models and their style is in accordance with scholastic science, with reliance on ancient authorities and humoral medicine $^{20}$. Much of eighteenth-century medical literature shows less radical

17 See D. Atkinson, The evolution of medical research writing from 1735 to 1985: the case of the Edinburgh Medical Journal, Applied Linguistics 13 (1992), 337374, and T. Hiltunen, Scientific journals: Philosophical Transactions and Edinburgh Medical Journal, in I. Taavitsainen and T. Hiltunen (eds.), Late Modern English medical texts: writing medicine in the eighteenth century, cit., 317-326.

18 For the beginning of the nineteenth century, see R. Porter, Disease, medicine and society in England, 1550-1860, cit., 45-58.

19 The diffusion of knowledge from learned Latin texts into the vernaculars started with medieval encyclopaedic works and expanded to technical and scientific texts, including medicine (see P. Pahta and I. Taavitsainen, Vernacularisation of scientific and medical writing in its sociohistorical context, in I. Taavitsainen and P. Pahta (eds.), Medical and scientific writing in late medieval English, Cambridge, Cambridge University Press, 2004, 1-22). The south of Europe led the way, but gradually the boom spread to other parts of the continent, reached Britain in the last quarter of the fourteenth and the north of Europe at the beginning of the sixteenth century.

20 The means of expressing abstract notions and relations were still deficient in 
changes than the Royal Society writings in the previous century, as the lines initiated in the latter half of the seventeenth century for spearhead learned writing continue. Texts for heterogeneous audiences still preserved their old humoral basis until the late modern period (and beyond), and the old scholastic style of writing had an afterlife in the most popular layers, albeit in a somewhat modified form ${ }^{21}$. The multilayered field of medical literature has another layer that goes even further back in time to the Anglo-Saxon period. The remedy book tradition contains recipes and prognostications recorded, e.g., in an eleventh-century Leechbook $k^{22}$, and thus the continuity of this trait in 1800 stretches back some seven centuries. Recipes were collected in monograph volumes but they also appear on flyleaves and margins of books, or added as ad hoc notes between other kinds of texts.

Knowledge distribution could also employ other channels. Medical consultation by post was an extension of private practice and provided an opportunity for the upper and upper middle classes to acquire medical knowledge ${ }^{23}$. The ephemeral printed materials of earlier periods include almanacks of two kinds, perpetual and yearly, which in the medieval and early modern periods contained medical texts of health advice. In this respect they overlapped with pamphlets and loose leaflets, but in the eighteenth century these ephemeral materials adopted new tasks with growing commercialism and began to market commodities and medical services with advertisements. Newspapers had started to appear regularly in London already in the first decades of the seventeenth century ${ }^{24}$, and con-

English, and blurred passages in the early texts give evidence of the difficulties in rendering the meanings in the vernacular.

21 See the following essays by I. Taavitsainen: The pragmatics of knowledge and meaning: corpus linguistic approaches to changing thought-styles in early modern medical discourse, in A. H. Jucker, D. Schreier and M. Hundt (eds.), Corpora: pragmatics and discourse papers from the 29th International conference on English language research on computerized corpora (ICAME 29), Amsterdam, Rodopi, 2009, 37-62; Meaning-making practices in the history of medical English: a sociopragmatic approach, cit.; Scholastic genre scripts in English medical writing 1375-1800, in R. J. Whitt (ed.), Diachronic corpora, genre, and language change, Amsterdam, Benjamins, 2018, 95-115.

22 C. E. Wright, Bald's Leechbook. Facsimile of British Museum Royal MS. 12.D.xvii, Early English Manuscripts in Facsimile 5, Copenhagen, Rosenskilde, 1955.

23 See W. Wild, Medicine-by-post: the changing voices of illness in eighteenthcentury British consultation letters and literature, Amsterdam, Rodopi, 2006.

24 See R. Facchinetti, N. Brownlees, B. Bös and U. Fries, News as changing 
tinued to distribute medical news among other topics. The first periodical magazine, The Gentleman's Magazine (GM), was established in 1731, in the same decade as specialized medical journals. It dealt with medical topics and reproduced material from other media, newspapers and monographs. Its selection ranges wide and reflects polite society readers' tastes and social practices, e.g. by publishing occasional poems inspired by recovery from illness, reflections on attacks of gout, odes to health, commemorations of the deceased and other miscellaneous topics that have to do with medicine $e^{25}$. One of the hot topics in the eighteenth century was small pox, and it inspired a reader with the pseudonym 'Inoculated' to pen some lines that take sides in the current inoculation conflict ${ }^{26}$ :

(5) Address to the Small Pox. Inscrib'd to Miss N. B.

SPoiler of beauty! for this once forbear,

To print thy vengeance on this blooming fair,

O spare those brilliant eyes, that angel's face,

Nor heav'n's fair portrait with thy spots disgrace.

Wisely determin'd to prevent the foe,

Nor wait unguarded to sustain the blow... (LMEMT, GM, 1755, 276)

\section{ROYAL SOCIETY NEW SCIENCE IN THE EIGHTEENTH CENTURY}

\subsection{The matter-of-fact principle}

Learned medicine rested on new grounds and reflected the principles inherited from the Royal Society period. Empirical evidence from

texts: corpora, methodologies, analysis, Newcastle upon Tyne, Cambridge Scholars Publishing, 2012.

25 The GM part of the LMEMT corpus is more comparable to 'Medicine in society' in EMEMT than any of the other categories of our corpora. Verse is not included in LMEMT.

26 Several genres and types of texts were involved from scientific treatises to entertaining narratives: I. Taavitsainen, Polite society language practices: Letters to the Editor on medical issues in The Gentleman's Magazine 1731-1800, in I. Taavitsainen and T. Hiltunen (eds.), Late Modern English medical texts: writing medicine in the eighteenth century, cit., 129-144. In addition to the piece of verse, several others were published in GM, as well as anecdotes of the origins of the method, how vaccination was introduced into Britain by Lady Montague, and paraphrases of professional texts connected with the controversy. 
experiments with new instruments and new techniques as its basis provided an important corner stone and the matter-of-fact principle is frequently mentioned in eighteenth-century texts, e.g.

(6) Because Experience is equally the Foundation and Touchstone of all reasoning in Physick, we will here submit our Solution to common Observations, and try whether every thing proposed in it, does not exactly answer Matters of Fact, and the visible Operations of Nature (LMEMT, Cockburn, The practice of purging and vomiting medicines, 1705, 2)

This principle was built on the tenet that everybody could verify what was happening, although the causes could be debated, but it was not without problems because of the complicated nature of repetitions $^{27}$. Scientific experiments had to meet the criteria of replicability and objectivity. They were conducted in front of Royal Society members that formed a closed circle of the first scientific discourse community in Britain and the eye-witnesses' names were carefully recorded in the PT. The new genre of experimental essays had been developed for reporting on the experiments with set conventions of writing in firstperson singular narrative in the present tense ${ }^{28}$. The style seems to continue in the PT and the EMJ in the eighteenth century.

\subsection{Technological advancement}

Topic 5 of our Digital humanities assessment reflects technical advancement in the new science and progress with experiments in professional medicine with the ratio of 5.13 in EMEMT against 17.12 in

27 See e.g. S. Shapin and S. Schaffer, Leviathan and the air-pump: Hobbes, Boyle, and the experimental life, Princeton, Princeton University Press, 2011.

28 L. Moessner, The birth of the experimental essay, in V. Bhatia and M. Gotti (eds.), Explorations in specialized genres, Bern/Berlin, Peter Lang, 2006, 59-77; D. Banks, Establishing the boundaries and creating the genre of the scientific research article in the late seventeenth century, Recherches anglaises et nord-américaines (special issue, ed. by J.-J. Chardin, Discourse, boundaries and genres in English studies: an assessment) 50 (2017), 31-42; and I. Taavitsainen, Historical discourse analysis: scientific language and changing thought-styles, in T. Fanego, B. Méndez-Naya and E. Seone (eds), Sounds, words, texts and change, Amsterdam, John Benjamins, 2002, 201-226. 
LMEMT $^{29}$. Advances in clinical practice more broadly contributed to changes in medical thinking, and new instruments such as the microscope, devised in the last decades of the seventeenth century, gave a new boost to science by opening up micro-level phenomena for closer scrutiny in medicine and the natural sciences. London was an important center for instrument-making trade and by 1700 it had a complex network of producers and retailers ${ }^{30}$. The new scientific requirements and community practices using new physical instruments inspired scientists to explore and make novel discoveries in the micro world. Their influence on eighteenth-century medical thinking was profound and there is a direct continuum through several centuries up to the present. The new instruments, particularly the microscope and the telescope, the electric machine and the air pump, were also purchased for domestic households «through the social scale», and became sources of entertainment in many homes in accordance with the new eighteenth-century boom of popularizing science ${ }^{31}$. In medicine, the microscope opened up new worlds in excursions to the unknown like the parenchymous tissues reported on, with reference to the matter-of-fact principle, by the Inquisitive Mr. Edmund King:

(7) For I saw (and so must any, that will attempt this work) in my endeavouring to preserve one Vessel of a traceable magnitude, I spoiled an infinite number of others less discernable, which were as truly Vessels, as the other, differing only in size and figure (as to appearance.) ... I began to think with my self, That it was not impossible for these parts to consist wholly of Vessels curiously wrought and interwoven (probably for more Uses, than is yet known;) ... (EMEMT, PT, 1666, 316)

Observations on anatomical facts by the microscope, as described

29 Topic 5 Keywords: blood parts body vessels motion air animal part nature matter heart state glands action bodies animals arteries natural nerves.

30 G. L'E. Turner, Eighteenth-century scientific instruments and their makers, cit., 527. In the field of surgical and anatomical practice, innovations seem to pertain to new equipment made of steel designed to provide aid to deformed bodies: see e.g. A. Withey, Household medicine and recipe culture in eighteenth-century Britain, cit. In the field of midwifery, a new mechanical tool, the obstetric forceps, contributed to rapid development of the field.

31 G. L'E. Turner, Eighteenth-century scientific instruments and their makers, cit., 527, 517, 534. 
e.g. in the above report, revealed new facts of the human body and its tissues and gave an incentive to develop new theories that became influential especially during the first decades of the eighteenth century, from c. 1700 to 1740 . Fibres were conceived as the minimum bodily components, and the human body came to be seen in a new light as a mechanical system in its own right made up of membranes and vessels in various textures ${ }^{32}$. In addition, fibres played a role in the common understanding of how health was maintained or disturbed: free circulation of the fluids through the solids meant health, whereas an obstruction of some sort could cause disease ${ }^{33}$.

Interestingly, the keywords also include nerves. From the 1740s onwards this line of thinking received an altered focus, connected with the rise of the nervous system in medical theory ${ }^{34}$. Nerves became «medicalized, academized, globalized, climatized, electrified, genderized and sexualized» ${ }^{35}$. One of the outcomes is a new kind of literature, initiated by George Cheyne in 1733 with his book The English Malady, which described a new kind of disease, called by that name. Its symptoms were a special kind of anxiety and depression, and the sufferer of this malady was very different from the melancholy figure of the previous century. He was very much a creature of the polite society: mobile, affluent, and urban. With this trend, nerves began to differentiate between social classes so much so that Jane Austen characterizes Mrs. Bennet with her aspirations to rise in societal esteem somewhat ironically in terms of her nerves.

\subsection{From alchemy to chemistry}

One of the topic strings contains keywords that point to the four elements and (al)chemical experimentation (EMEMT 4.99, LMEMT

32 H. Ishizuka, 'Fibre Body': the concept of fibre in eighteenth-century medicine, c. $1700-40$, cit.

33 C. Lawlor, Consumption and literature: the making of the romantic disease. Basingstoke, Palgrave Macmillan, 2006, 45.

$34 \mathrm{H}$. Ishizuka, 'Fibre Body': the concept of fibre in eighteenth-century medicine, c. $1700-40$, cit., 597.

35 G. S. Rousseau, Towards a semiotics of the nerve: The social history of language and a new key, in P. Burke and R. Porter (eds), Language, self and society: A social history of language, London, Polity Press, 1991, 213-275, here 221. 
$8.21)^{36}$, and connects with the separation of alchemy, as a pseudoscience, from chemistry, although the division was not clear ${ }^{37}$. The medical faculty in Leiden was an important center for the new science of chemistry and the pioneer in teaching drug preparation in a laboratory (Turner 2003: 525). The subject was taught by Herman Boerhaave (1668-1738), whose tuition attracted medical students from England as well as from elsewhere in Europe. In addition, Boerhaave's books were translated into English, but there is also pseudoliterature with occult elements in English in his name (see LMEMT), which shows the fuzziness of the area. The changes in the field were rapid and inspired the above-mentioned dictionary maker James Ker to remark «[t]he progress of Chemistry within the last twenty years has been more rapid than was ever made in any science in an equal period $\gg^{38}$.

\section{RISING PROFESSIONALISM IN THE EIGHTEENTH CENTURY}

The professionalization of medicine stands out as the most conspicuous change of the period in quantitative terms, indicating the difference between the early and the late modern medicine with the ratio 6.85 for EMEMT and 27.30 for LMEMT ${ }^{39}$. It came out clearly beyond our expectations, and contains several different trends. Our results indicate that professionalization has been somewhat underestimated in the earlier literature and needs further discussion.

\subsection{From individual cases to statistics and probabilities}

A trend from single to multiple case studies had already been noticed in the earlier period ${ }^{40}$. Gradually it led to calculating probabil-

36 Topic 6 Keywords: water salt spirit fire acid quantity salts made volatile urine waters oil sulphur parts tincture wine common earth taste.

37 Many scientists had alchemical pursuits, including Isaac Newton: see S. Mandelbrote, Footprints of the lion: Isaac Newton at work, Cambridge, Cambridge University Library, 2001, 110.

38 J. Ker, The first part of a dictionary of chemistry $\&$ c, Birmingham, n.p., 1789, iii.

39 Topic 1 Keywords: physicians great nature diseases practice physician time medicines method art made knowledge general mr medicine make dr men persons.

40 See A. Lehto and I. Taavitsainen, Medical case reports in Late Modern 
ities, which is a valid method even in present-day medicine. The progress in cutting-edge science of the eighteenth century can be exemplified by texts of the inoculation controversy with arguments pro and con; the adversaries were arguing on religious and patriotic grounds, sometimes even with xenophobic tones, but James Jurin (1687-1750) used statistical evidence to convince his readers of the benefits of the new practice. He collected data and calculated the relative odds of dying from smallpox inflicted by inoculation, roughly 1 in 50, whereas the death rate in natural smallpox was 1 in 7 or 8 :

(8) ... 9 is the Number of Persons, who have been suspected to have died of Inoculation; so that, if this Operation was really the Cause of all their Deaths, the Hazard of dying of the inoculated Small Pox must be that of 9 in 440, or 445, that is, of one in 49, or 50. (LMEMT, Jurin, An account of the success of inoculating the small pox in Great Britain, 1724, 23)

Jurin's calculations were published both in a monograph from 1724 and in annual pamphlets from 1723 to 1727 . His contribution to medical science was considerable in introducing a new thought style, and his radically new strategy of stating the superior benefits of smallpox inoculation by numerical figures succeeded in convincing people. He won the battle. Other pioneers of the statistical approach include William Black (1749/50-1829). He had studied medicine at the universities of Edinburgh and Leiden, and contributed to the advent of the new thought style in the last decades of the century by surveying London bills of mortality, with correlations plotted against some variables such as the seasons and the environment ${ }^{41}$.

\subsection{Increasing precision and social problems}

Another topic string enhancing the patients' side of medical care brought forth other aspects of professionalization, above all the growing interest in public health concerns, with the ratio of 7.63 in EMEMT

English, in I. Taavitsainen and T. Hiltunen (eds.), Late Modern English medical texts: writing medicine in the eighteenth century, cit., 89-111.

41 W. Black, Observations medical and political on the small-pox and the advantages and disadvantages of general inoculation, especially in cities, London, J. Johnson, 1781. 
and 22.33 in LMEMT ${ }^{42}$. Several of the terms were connected with time in an increasing scale of specificity. It shows how general notions like 'time' and 'things' give way to more specific terms in LMEMT. The change is connected with the new science: methods and symptoms as well as organs of the body (bladder, kidneys) become more enhanced, too. The shifting viewpoint with focus on patients and a new concern with people's welfare can be encountered in texts connected, for instance, with the Gin Bill debate against excessive alcohol consumption, which was a severe social problem in the first half of the eighteenth century. Public health issues were raised for the first time around this issue with a dismal picture of the situation in England with

(9) its Inhabitants being intoxicated and inflamed with this Liquid Fire, and thereby made capable of perpetrating the most enormous Wickedness; Such and So terrible are the Effects of Profligacy, Madness, and Misery, when they are blended together! (LMEMT, GM 1743: 189).

\subsection{Changing community practices in medical care}

A new discourse community practice had become common with the use of professional titles $D r$. and $M r$. This trend had been initiated already in the Royal Society period as recorded in the PT experimental essays, e.g. the above-quoted report by Edmund King (see example 7) gives evidence of the new usage by carefully listing the eye-witnesses with their titles: «Mr. Boyle, Sir William Petty, Dr. Williams, Dr. Lenthal, Dr. Jaspar Needham, Dr. Samson ...». Eighteenth-century texts follow the same practice in other genres of writing, e.g. in treatises connected with polemical issues:

(10) ...the Plot of Mr. Douglass's whole Performance begins to open, when he says, that the Midwomen's want of Knowledge is more their Misfortune than their Fault, ... But now it must hereafter be their Fault more than their Misfortune ... This is the first Act of Mr. Douglass's Farce ... (LMEMT, Chapman, Reply to midwifery in London, 1737, 9)

This quote is from a controversy of midwifery, which was one of

42 Topic 7 Keywords: time disease great day patient fever water years days symptoms pain case found cold cure blood small bours stomach. 
the fields with major changes in the eighteenth century. Traditionally, assisting at birth had been the midwives' task and the practice continued, but the advent of a new kind of birth attendant changed the hierarchy: men midwives had better access to the new knowledge base and could thus introduce theoretical advances. Embryology became an area of competing views and ideological standings ${ }^{43}$. It is however somewhat surprising that the string with keywords pertaining to childbirth and surgery did not indicate a big difference between the periods (EMEMT 9.96 and LMEMT 8.12) $)^{44}$. The explanation can be found in the general nature of the keywords. They are common terms of newborns' anatomy independent of the practices in the field. The seventeenth-century literature on midwifery in EMEMT comprises several important contributions, from the 1540 Byrth of mankynde - the English translation of the Latin treatise by E. Rösslin - to Jane Sharp's The midwives book of 1671 , the first printed midwifery manual written by a woman ${ }^{45}$.

\section{DeCLINING TRENDS}

There are several strings that display a diminishing trait in late modern medicine. They are connected with some general characteristics of the period rather than medical practice itself, but when transferred to the world of science, the trend is from the top downwards to marginalized positions (see Section 8.3. above).

\subsection{Old authorities}

The aim of science, up to the dawn of the early modern period, was to reconstruct the uncorrupt meanings of original texts by ancient authorities, as they were believed to contain a treasure trove of perfect

43 For an overview, see P. Pahta, Midwifery, in I. Taavitsainen and T. Hiltunen (eds.), Late Modern English medical texts: writing medicine in the eighteenth century, cit., 271-278.

44 Topic 9 Keywords: part parts child wound, head made bones called side great bone wounds hand neck place woman left skin small.

45 See P. Pahta and M. Ratia, Treatises on specific topic, in I. Taavitsainen and P. Pahta (eds.), Early Modern English medical texts: corpus description and studies, Amsterdam, John Benjamins, 2010, 73-100. 
wisdom. The mode of knowing in scholastic science was logocentric with firm reliance on authorities (EMEMT 8.12, LMEMT 0.99) ${ }^{46}$. At the dawn of the sixteenth century, the absolute reliance on the written word had given way to more critical attitudes. Direct evidence of this process can be found in Walter Bailey's Account on the three kinds of pepper, as he saw how very unlike the ancient inherited descriptions and the real plant were. This observation made him conclude that «the old authors, I mean Dioscorides, Galen, Plinie, Auicenna, Serapio, and other writers of the former time were deceived» (EMEMT, 1588, A5). The process continued so that by the Royal Society period book wisdom had given way to observation as the mode of knowing that irrevocably changed what people knew and thought about the natural world ${ }^{47}$. The changed attitude to knowledge also shows in the more tentative modality of writing (see example 7).

\subsection{The diminishing role of humours and elements}

One of the most conspicuous changes was the diminishing role of humours and elements (EMEMT 20.39, LMEMT 3.30), but the layers of writing differ from one another greatly in this respect, too. By the late modern period, most medical texts enhance observation and the change in the mode of knowing from logocentric to empirical knowledge was almost completed ${ }^{48}$. The LMEMT corpus has been compiled to be as representative as possible of the professional layers of medical texts $^{49}$, but the more popular writings where the old conceptions lingered on are more difficult to reach and the total picture may well be somewhat deficient without them. The old traditions deriving from ear-

46 Topic 0 Keywords: called man herb good moon stone english hath named grows leaves water long white colour day great seed.

47 See A. Grafton, A. Shelford and N. Siraisi, New worlds, ancient texts: the power of tradition and shock of discovery, Cambridge, MA/London, The Belknap Press of Harvard University Press, 1992, 1-5, and S. Shapin, The scientific revolution, Chicago, The University of Chicago Press, 1996, 1; see also I. Taavitsainen, Historical discourse analysis: scientific language and changing thought-styles, cit., 204.

48 Topic 2 Keywords: body blood doth cold good humours stomach beat hot nature dry hath parts things part natural flesh meat moist.

49 See T. Hiltunen and I. Taavitsainen, Towards new knowledge: the corpus of Late Modern English medical texts, in I. Taavitsainen and T. Hiltunen (eds.), Late Modern English medical texts: writing medicine in the eighteenth century, cit., 1-16. 
lier centuries were still adhered to and the humoral system persisted in writings based on simple rules of health, medical astrology and calendar $\operatorname{lor}^{50}$. The strands of practice are very different in this layer as common people mostly sought for advice and rules of conduct for better living in this literature.

A string that refers to health advice and recipes poses problems of interpretation, too. The statistics show a clear diminishing trend and the keywords are essentially those connected with making medicine in the traditional way ${ }^{51}$. Recipes had been one of the three main traditions of medieval medical writing (the others were specialized texts and surgical treatises) and the importance of the field continues in the early modern period; in EMEMT the ratio is 15.35, while in LMEMT it has sunk to 6.00. An explanation could be sought in the new trend of 'dispensaries' or institutional recipe collections included in LMEMT, as they may display different features. Increasing commercialism, with the first steps of industrialization, may also be at play here ${ }^{52}$, but this issue needs verification in future studies. Health advice is gathered into Category 4 of Regimens. In the overall picture of eighteenth-century medical writing, they seem to have a less prominent position than in the early modern period ${ }^{53}$.

\subsection{The diminishing role of religion}

A third string that shows a diminishing trend has a miscellany of keywords ${ }^{54}$, but god, man, and life point to religious concerns (the ratio is EMEMT 18.78 and LMEMT 5.08). A step towards fragmentation had

50 See I. Taavitsainen and G. Schneider, Scholastic argumentation in early English medical writing and its afterlife: new corpus evidence, in C. Suhr, T. Nevalainen and I. Taavitsainen (eds.), From data to evidence, Leiden, Brill, 2019, 191-221.

51 Topic 3 Keywords: water put half oil ounce powder make wine ounces drink good white morning till juice leaves warm pound vinegar. Britain, cit.

52 See A. Withey, Household medicine and recipe culture in eighteenth-century

53 See D. Gentilcore, Regimens and their readers in eighteenth century England and C. Suhr, Regimens, both in I. Taavitsainen and T. Hiltunen (eds.), Late Modern English medical texts: writing medicine in the eighteenth century, cit., 75-87 and 289-297 respectively.

54 Topic 8 Keywords: man hath things men god great good body time nature thing doe life make reason made physic physicians doth. 
been taken in the sixteenth century when the Western European unified religious order of Catholicism had become split into two main sources of authority in Protestant countries with the separation of the State from the Church $^{55}$. The world picture had undergone radical changes and the alterations continue in the late modern period; notions like 'bewitched' and 'devil' are found in EMEMT, but this vocabulary is completely absent from LMEMT ${ }^{56}$. Topic 8 is connected with the religious system and shows how it was played down and secular values gained ground. A steady decrease in the role of Heaven started already in the late medieval period as a more secular world picture gained ground: healing was not only up to the Providence, but medicine could actively aid in restoring health. A more detailed survey of the earlier literature reveals that two different processes are involved and worked simultaneously: secularization (as above) and disenchantment. The disenchantment model with the decline of astrology, magic and occult thinking ${ }^{57}$ is complicated and difficult to trace, as evidence is scattered and largely uncharted. In general, these traits at the popular end of the scale counterbalance the rationalization claim based on more elite practices.

\section{TOWARDS THE END OF THE CENTURY}

It had been up to the Church and religious communities to care for the sick in the earlier times, but altered attitudes to public welfare in the eighteenth century gave an incentive for founding secular institutions that altered the field ${ }^{58}$. Medieval hospitals had been run in connection with religious establishments, but the new provincial infirmaries and their metropolitan counterparts were an eighteenth-century invention ${ }^{59}$. The care of mentally ill patients was new, and by drawing attention to it,

55 S. Shapin, The scientific revolution, cit., 124.

56 See I. Taavitsainen, G. Schneider and P. M. Jones, Topics of eighteenth-century medical writing, in I. Taavitsainen and T. Hiltunen (eds.), Late Modern English medical texts: writing medicine in the eighteenth century, cit. Books, 1971.

$57 \mathrm{~K}$. Thomas, Religion and the decline of magic, Harmondsworth, Penguin

58 See A. Lehto, Public health, in I. Taavitsainen and T. Hiltunen (eds.), Late Modern English medical texts: writing medicine in the eighteenth century, cit., 307-315.

59 M. Fissell, The disappearance of the patient's narrative and the invention of 
the Manchester infirmary could set an example to other parts of the country. In addition, a different kind of development can be seen in the social order with fashionable cures of sea bathing in various resorts and spas became socially important and drew polite society members to spas e.g. in Bath and sea-bathing institutes e.g. in Margate, Kent ${ }^{60}$.

London had been the center for much of the innovations earlier, and was growing rapidly especially during the second half of the centu$\mathrm{ry}^{61}$, but other centres of learning like Edinburgh were rising in the eighteenth century ${ }^{62}$. Manchester, York, Sheffield and Bristol ${ }^{63}$ also increased in size and importance with the first steps of industrialization and contributed to the advent of the consumer society. A great deal of attention has been paid to elite practices in eighteenth-century professional literature. The following praise gives evidence of the new spirit in initiatives behind the charitable institutions. The passage below discusses the utility of hospitals, and the need for more:

(11) Never were the rights of humanity better understood, nor the feelings of compassion more indulged than in our age and country. Of this we have a pleasing proof in the rapid success attending every charitable institution. We have seen, within less than half a century, numerous edifices arise throughout the kingdom, dedicated to the support of the poor under the severe afflictions of disease and want-we have seen these amply maintained, carefully inspected, and diligently attended; and all this without any interference of the civil powers, merely by the generous and disinterested zeal of individuals. In the Metropolis many new designs have been set on foot for the relief of particular diseases and calamities; in the country general Infirmaries have been estab-

hospital medicine, in R. French and A. Wear (eds.), British medicine in an age of reform, cit., 92-109.

60 See Taavitsainen I. Taavitsainen, Professional and lay medical texts in the eighteenth century: a linguistic stylistic assessment, in I. Taavitsainen and T. Hiltunen (eds.), Late Modern English medical texts: writing medicine in the eighteenth century, cit., 173-197.

61 See E.A. Wrigley, Poverty, progress, and population, Cambridge, Cambridge University Press, 2004, 256-259.

62 See A. Cunningham and R. French (eds.), The medical Enlightenment of the eighteenth century, cit., 1-3.

63 See M. Brown, Performing medicine: medical culture and identity in provincial England, c. 1760-1850, Manchester, Manchester University Press, 2011, and M. Fissell, Patients, power and the poor in eighteenth-century Bristol, Cambridge, Cambridge University Press, 1991. 
lished at almost every considerable town, upon the most liberal and extensive principles. (LMEMT, Aikin, Thoughts on hospitals, 1771, 5)

The concern for people's welfare and change in attitudes broadened the interests in healthy environments, and more attention started to be paid to sanitation and hygiene in densely populated areas. It proved necessary, as urban developments with rapid population growth showed the old systems untenable and insufficient.

The late eighteenth century overseas trade was blooming, and this period also saw the widening of the British Empire to the Southern hemisphere, with its peak in the following century. Captain Cook's explorations in the Pacific (1768-80) were followed by the first settlements in Australia (1793) and South Africa $(1795)^{64}$. These developments presented increasing opportunities for the upper and the upper middle classes. The achievements at sea and in the new continents enhanced the national feeling and the advances in medical care contributed, too: British welfare institutions were regarded as an index of national greatness and a cause of pride. Rising patriotism gave an incentive to improvements in the army and the navy, and overseas conditions with health hazard like tropical fevers were discussed with concrete suggestions for amendment. Attention was paid to British sailors' miserable diet and diseases like scurvy, and there was a vivid discussion in GM about the topic at the very end of the century:

(12) EVERY hint that has a tendency to better the condition of British sailors, the brave assertors of our country's independence, will, I am certain, be well received ... There are some evils to which this class of men are exposed, which the utmost attention on the part of Government, as well as on the part of their respective commanders, cannot at all times prevent. You will perceive that I allude to the diseases incident to a seafaring life ... the Scurvy. Of late years, several naval physicians and surgeons have done much towards the prevention and cure of this disorder; ... (LMEMT, GM, 1798, 823)

64 For the roots of the British Empire in the early modern period, see R. Johnson, The British Empire: pomp, power and postcolonialism, Humanites-Ebooks.co.uk, 2007. In the eighteenth century, wars were waged in North America, but settlements in India were often close to their native subjects: see R. Johnson, The British Empire: pomp, power and postcolonialism, cit., chapter 1 , for an overview. 
Another Letter to the Editor gives concrete advice for improving the diet:

(13) Mr. Urban, ... I AM pleased to see that my hints respecting the use of raw carrots in the Sea-scurvy have served to call forth the attention...; but I beg leave to inform him, that ... in many instances they have had a beneficial effect; but, on the whole, they have been found much less powerful in counteracting the Marine-scurvy than the vegetable acids, and more especially than fresh fruits and fresh roots. ... but, next to the fresh juice of lemons, vinegar, spiced with ginger and mustard-seed, is the best acid that can be employed in the Sea scurvy. (LMEMT, GM, 1798, 1029)

Another important line of reform has to do with professional organization of the faculty and conditions of medical practice in general, which had been largely uncontrolled. The authority and control of a small elite group of the College of Physicians, which was «originally founded for the most beneficent and liberal purposes» (LMEMT, Stanger, A justification of the rights of the licentiates, 1798, preface), was no longer accepted as such, but voices demanding change were raised during the last decade of the eighteenth century:

(14) A CORPORATE monopoly in a liberal and Scientific profession, which depreciates the great body of that profession, without the slightest evidence of their inferiority or disqualification, would scarcely be supposed to exist at the close of the eighteenth century, in the enlightened metropolis of Great Britain. But, extraordinary and disgraceful as it is, a great majority of the physicians of London, equal in talents, education, acquirements, skill, and conduct, to any body of the faculty in Europe, are only tolerated and licensed to practise under the authority and control of a narrow corporation ... (LMEMT, Stanger, A justification of the rights of the licentiates, 1798, preface)

\section{CONCLUSIONS}

By the year 1800 changes had already altered the field of medicine in Britain to the more modern direction. The examples of the last decades given above show how the scope for human healing agency had increased with moving away from earlier predominantly religious ways of thinking. The new worldview gave more space to medical care, and hospitals and other institutions improved the conditions for the 
patients. The British Empire was expanded in the eighteenth century, and Britain ruled over the seas. The long voyages with new environments in land presented unknown health hazards and posed challenges that gave an incentive to develop cures for tropical diseases and to pay increasing attention to military and maritime medicine. Debates in the written form about the professional organization of medical practice in the country were active at the end of the century. Demands for renewed practices in the field received favourable response. The year 1815 marks the watershed between unregulated medical practice and introduced state supervision over entry to medical practice ${ }^{65}$, but what had preceded it shows the importance of the eighteenth century in this respect, too. The organization of professional tasks and divisions of labour were centred in London, but the situations in other parts of the country deserve to be noted as well. Public health developments all over the country gave an incentive to infirmaries and asylums, and to sea-bathing institutes and spa resorts that became important parts of the new life styles of the polite society. Thus the changes influenced the lives of the upper and middle layers of society both at work, health care and leisure. This century also saw improvements in poor relief and increasing concern for welfare in Britain in general. The development of media for distributing news and knowledge was rapid and versatile the eighteenth century. The innovative specialized journals of medicine paved the way to modern practices, but the present assessment also gives evidence of the large area of texts published in monographs and booklets and how they contributed to the change. The LMEMT corpus is compiled to be as representative as possible of professional medicine, but the most progressive media of periodicals had to be left out of the digital study for practical reasons ${ }^{66}$. Likewise the most ephemeral materials of popular medicine with the oldest layers of remedy book tradition was beyond reach.

The aim of the present article has been to give an overview of diachronic developments in English medical writing from 1700 to 1800. The report is largely based on an earlier digital humanities study that

65 See S. C. Lawrence, Private enterprise and public interests: medical education and the Apothecaries' Act, 1780-1825, cit.

66 This part was not ready for use yet, and there is a need for further studies in this area, too. 
revealed tendencies of change in the LMEMT corpus, but it also pointed out what remained stable and what diminished in importance. This earlier corpus assessment was able to bring new precision to the timings by pinpointing texts that introduced new ideas. As a result, it was possible to draw a more precise timeline of the changes in the eighteenthcentury than had been done before. Both the cutting-edge media and the popular end of the scale deserves more study. The historical pragmatics approach enhances the role of context in interpretations by focusing on different types of social practice and putting the developments in the period frame. The point of departure for this article has been what changed and what remained constant in the eighteenth with its various elements and objects of inquiry, scientific methods, evidence and evaluation ${ }^{67}$. This meant probing into the long roots to the continuities from late medieval to the early modern and the dawn of the new science in the latter half of the seventeenth century, assessed with both a quantitative digital humanities method and qualitative discourse analysis, but also taking excursions to the future developments. How the story continues in the nineteenth century remains to be seen with future studies.

67 See A. C. Crombie, Styles of scientific thinking in the european tradition: the bistory of argument and explanation, especially in the mathematical and biomedical sciences and arts, cit., vol. 1, 6 . 